\title{
Yakym Yarema's philosophical and pedagogical ideas in discursive practices of education
}

\section{KEYWORDS}

Aristotle, Franz Brentano, Kazimierz Twardowski, Yakym Yarema, educational discourse, philosophy of education

\begin{abstract}
Honcharenko Olha Yakym Yarema's philosophical and pedagogical ideas in discursive practices of education. Kultura Społeczeństwo - Edukacja nr 2(12) 2017, Poznań 2017, pp. 313-327, Adam Mickiewicz University Press. ISSN 2300-0422. DOI 10.14746/kse.2017.12.15.
\end{abstract}

In this paper on the basis of comparative analysis the similarity of Yakym Yarema's and Kazimierz Twardowski's main philosophical and pedagogical ideas has been identified. The analysis of these ideas proves that Ukrainian scientist represents Twardowski's educational practices as well as reflects the traditions of Vienna philosophical school by Franz Brentano which history goes back to Aristotle's philosophy. The value of Yakym Yarema's philosophical and pedagogical ideas in the present educational discourse has been shown in the article.

1.

Yakym Yarema (1884-1964) is a prominent figure of Ukrainian cultural life first half XX century. He was a professional philosopher and psychologist, a reputable researcher of Ukrainian ethno psychology and psychology of creativity, a talented teacher, an institutor and a public figure. As it is shown in the results of Stepan Ivanyk's studies, Yakym Yarema belonged to the group of western Ukrainian scientists of the interwar period who were in the discursive range of Kazimierz Twardowski philosophical school through which they joined the Vienna tradition of philosophical school of Franz Brentano (1895-1939) (Ivanyk, 2014: 187). Phi- 
losophy course that was taught by the creator of Lvív-Warsaw school has focused Yakym Yarema's interests on psychologism, introspectionism and the analysis of literature (Ivanyk, 2014: 165-177). Do Yarema's philosophical and pedagogical ideas reflect the discursive practices of Twardowski school in educational area? Do they promote the designing of the discursive practices in educational area? An attempt to answer these questions is the aim of this paper. The approach to achieve this goal is based on the distinguishing of two related meaning of discourse such as reflective and constitutive. "The first means the language that reflects social, epistemological and rhetorical practice of a specific group as some discourse; the second indicates the language ability not only to reflect this practice, but also to constitute it" (Джоліф, 2003: 127). The definition of the discourse as different dimensions of social structure is also derived from Foucault's characteristic of the discourse as a practice "that systematically creates spoken objects" (Foucault, 1972: 49).

\section{2.}

Yarema acutely aware crisis tendencies in contemporary education caused by the emergence of mass society in the twentieth-century history. So he had to admit the narrowing of the education purpose to legitimize knowledge as well as narrowing objectives of the school to the factory of certificates "that allows admission to the government" (Ярема, 2003: 113). According to scientist's observations, contemporary youth have been instilled misconceptions about the education purpose and have been formed on this basis false educational values and ideals. This led to the fact that the schools began to produce conformists for whom the benefits and value are identical concepts, and the material and non-material needs - consumption of knowledge. Despite this, Yarema insisted that the learning aim was to satisfy human thirst for knowledge. However, he stressed that any study can be useful only if it develops student's mental abilities as a real gem of an educated person. Therefore, the scientist considered the school objectives not only as the knowledge acquisition, but also as the development of pupil's mental functions such as logical thinking, analysis and synthesis, abstraction, sense of beauty and goodness, strength of will. "Those who develop that ability in school - wrote Yarema - can easily continue their learning in various fields of knowledge and will be able to quickly overcome any obstacles in practical life" (Ярема, 2003: 113-114). The scientist was against mechanical hummering the educational material in students' memory, as this is contrary to the natural development of the human psyche. He preferred the inductive method of teaching as it allows student's mind to be active 
and to do by itself what deduction can give in the completed form. In the inductive learning Yarema stressed the importance of perception the objects and experimenting with them.

Yarema debunked another negative trend of the school of the twentieth century, namely the subordination education objectives in school by national education. Referring to prewar school's aim of education, he stressed that it, despite the subordination of the interests of the dynasty, still defended universal values: "The school does not impose young people a particular ideology. Basic general education, which young people got in school, has to become the basis for their free ideological determination during spiritual maturity" (Ярема, 1934: 191). Instead, on Yarema opinion, the school policy of mass society merges with public policy and the problem of school transformed into a public problem: to be or not to be? The researcher described the consequences of school entering in the phase of deep state and national differentiation as follows: "One common world of human history and culture is replaced by different small worlds of single state nations with their culture and history of unequal value, where are only here and there some weak links with the outside world. Each of these small new worlds has to put himself in the center of the historic space, gladly separating themselves from all not-self" (Ярема, 1934: 198). Such hasty isolating the cultural world of individual nation-states from alien world during the postwar period Yarema considered their returning to themselves, looking into themselves. He rightly observed that no nation in the world has created its cultural world by itself, as each nation always nurtures its cultural creativity by exterior influences and incentives. Hence, in the education aim the joint treasury of human values as the heritage of many national cultures can not be replaced by one nation itself. The scientist rejected the conventional view that education is only school matter. He believes that school is able to realize just the purpose of upbringing learning. Yarema proposed school to promote person's character formation because "we will say about the personality only when he/she has character" (Ярема, 2003c: $150)$. The scientist defined moral education as the basis of any education (social, public, national or state) (Ярема, 1937: арк. 7). He distinguished three stages of human moral development. In the first stage a child uncritically accepts from the adult ethics and the rules of behavior. In the second stage a teenager learns to distinguish the good actions from the bad ones due to adults' assessment. In the third stage a young man begins forming his/her own critical moral outlook. The third stage is a reflection of individuality's character. (Ярема, 1937: арк. 11-12). The responsibility for human autonomous moral consciousness formation Ukrainian scientist put on education (Ярема, 1937: арк. 12). 
He considered the psychological foundations of pedagogy the possibility of shifting the mechanical schooling into the intellectual cooperation. The scientist strongly believed that if a teacher knows psychology, he/she will be not a blind instrument of curriculum but an independent leader in search of means and methods of teaching and the development of students' mental abilities. Yarema determined the basis of educational psychology as following: general theoretical psychology, including pedopsyhology as the science of child mental life and its development (Ярема, 1928: 1). According to Yarema, psychology on the one hand helps a teacher to create the image of a student not as a psychological object but as a psychological personality and individuality. On the other hand, it helps a teacher to cognize himself/herself and to analyze critically his/her teaching. In this context, the scientist considered the intensive study of human natural inclinations by means of individual and differential psychology, psychotechnique and psyhografy the important school objective. Because this study is the guarantee of individualization and differentiation in teaching and further self-identity. However, the scientist realized that each individual development has its limits. So, he warned against pulling student's level to the general one or provoking ambitions inadequate to his/her own abilities. The urgency of child's individuality manifestation in school Yarema also linked with the necessity to young people of critical determination of their future. Decisive in choosing career the scientist believed child's free expression in the intellectual and physical labor. It could help teachers to examine students' psychophysical features and to make for them some recommendations concerning their future career choices. Yet, the scientist supported psychological diagnosis only on the basis of scientific psychology (Ярема, 2003c: 121).

To sum up, Yakym Yarema's philosophical and pedagogical ideas focus around issues such as education objectives and psychological basis of pedagogy. Obviously, the scientist did not support the school transformation from educational institution into the institution of pragmatic satisfaction the material needs. He also criticized the way mass society considers education (only from one point of view and just as a tool), ignores its own duty of youth education and, even worth, demoralizes young people by imposing them its own views on education. Yarema supported education oriented on the intellectual and moral needs of the individual that ensures individual autonomy. Therefore, he broke down with reproductive education and its false ideal of state-national ideology service. Yarema proposed to promote the becoming of a complete person by means of practically oriented science - educational psychology which is aiming at cognition of human nature.

It is essential that Twardowski also linked the learning aim with satisfying human thirst for knowledge (Twardowski, 1901: 3). This philosopher's approach to 
education goes back to Metaphysics of Aristotle, which begins with the words: "All men naturally desire knowledge" (Aristotle, 1989: Met. 1.980a). To achieve the aim of the article we should pay attention to philosophical and pedagogical ideas of Aristotle.

\section{3.}

The ancient Greek philosopher distinguished human desire for different knowledge. For the experienced know the fact, but not the wherefore; but the artists know the wherefore and the cause (Aristotle, 1989: Met. 1.981a). But according to Aristotle knowledge of the causes, though there is knowledge and understanding is not wisdom. Because wisdom does not set a utilitarian purpose, it seeks to know first reason for their own sake, not for any benefit. Wisdom is a universal knowledge that demands huge mental efforts and the high degree of abstraction, as "for sense-perception, being common to all, is easy, and has nothing to do with Wisdom" (Aristotle, 1989: Met. 1.982a). Universal knowledge is a general knowledge that the most difficult to learn, "because they are furthest removed from the senses" (Aristotle, 1989: Met. 1.982a). Thus, knowledge begins with perception, and from there by abstraction comes to concept. And based on the sensory material mind is able to cognize things in common. It should be noted that the ancient Greek philosopher believed that it is impossible for humans to possess universal knowledge: "God alone can have this privilege" (Aristotle, 1989: Met. 1.982b). But, he was convinced that "the acquisition of this knowledge, however, must in a sense result in something which is the reverse of the outlook with which we first approached the inquiry" (Aristotle, 1989: Met. 1.983a). So, people are concerned with the divine and can multiply it in their life: "If then the intellect is something divine in comparison with man, so is the life of the intellect divine in comparison with human life" (Aristotle, 1934: Nic. Eth. 10.7.8). Indeed, the life that corresponds mind makes a man happy. But did Aristotle consider happiness as the divine part or only chance in life? The philosopher used to think that happiness is the result of virtue, learning or exercises. And only in this sense he attributed it to divine and blessed. However, the philosopher thought happiness something common to many people, because due to learning and diligence it can belong to all. So happiness is the harmony with human nature. Thus, it is a mistake to entrust it to a case. Happiness is a kind of soul activity, agreed with virtue. However, Aristotle recognized both the intellectual and ethical virtues. Intellectual virtues arise through learning, and ethical - because of habit (Aristotle, 1934: Nic. Eth. 2.1.1). 
The philosopher connected intellectual virtue with two rational abilities: scientism and prudence. Scientific skills are induction and deduction, and prudence is making right decisions in general.

Aristotle did not link ethical virtues with human nature, as "for no natural property can be altered by habit" (Aristotle, 1934: Nic. Eth. 2.pos=15.2). For example, you can not accustom the stone which by nature falls down to rise up, tossing it at least a thousand times. Therefore, according to the philosopher, not by nature, but in spite of it, there are human virtues which a man gets through schooling. Significant value in acquiring ethical virtues he gave to practice: "We learn an art or craft by doing the things that we shall have to do when we have learnt it: for instance, men become builders by building houses, harpers by playing on the harp. Similarly, we become just by doing just acts, temperate by doing temperate acts, brave by doing brave acts" (Aristotle, 1934: Nic. Eth. 2.pos=17.4). Thus philosopher affirmed the urgent need for the development good character through person's virtuous deeds. He believed that parents should first teach a child to correct behavior. This habit is formed unconsciously, mainly because of parents' authority. But then the child will realize the essence of virtues and will give them a preference in a situation of choice. It is essential that the ancient philosopher did not limit the formation of human character by a certain period of life because he was confident that a virtuous man becoming is a lifelong process (Aristotle, 1934: Nic. Eth. 2.pos=38.8). Therefore, Aristotle attached great importance to education, by which he meant primarily moral education. The philosopher considered education nationwide issue, which purpose is caring about the formation of a dignified citizen as the only guarantee of stability throughout the state (Aristotle, 1934: Pol. 8.1337a). However, this does not mean that Aristotle aimed to subdue the man state. He sought a harmonious combination of human purpose and goals of the state. In his opinion, the state should create for human conditions for achieving the highest good, while the state itself reaches this good.

Aristotle gave psychology significant values of all sciences. This distinction among other sciences philosopher explained that the knowledge of the soul admittedly contributes greatly to the advance of truth in general, and, "above all, to our understanding of Nature, for the soul is in some sense the principle of animal life. Our aim is to grasp and understand, first its essential nature, and secondly its properties; of these some are taught to be affections proper to the soul itself, while others are considered to attach to the animal owing to the presence within it of soul" (Aristotle: On the Soul. 1.402a). Equally important is reasoning by the ancient Greek philosopher the importance of empirical investigation of the soul nature. According to Aristotle, the soul is the entelechy of the body and is inseparable 
from it. Soul is the cause and nature of a body. The philosopher distinguished three "levels" of soul: lower - vegetable, responsible for supply, growth and reproduction of living beings; average - animal, in which the preceding features are added by feelings and desires; higher intelligent, inherent to man, in which up to all the previous features added mind that shows its activity in a scientific and practical thinking. Undoubtedly, this interpretation human soul by philosopher revealed the possibility and availability of its knowledge and self-knowledge.

Summing up, philosophical and pedagogical ideas of Aristotle were concentrated around the definition of education objectives. The ancient Greek philosopher did not consider education as knowledge acquisition or practical skills formation. In his opinion, education is not a useful skill, but intellectual and moral virtue that helps a person to achieve his/her lifetime ambition - living dignified and happy life. Therefore, the purpose of education the philosopher considered development of person's mind and character. He believed that a state is responsible for providing conditions for people intellectual and moral life. Although Aristotle thought that the state is only a city, not a nation or an empire, he determined its true purpose: to subordinate education and upbringing to the aim of each person. Psychology as a science of the soul can promote this education purpose. The attraction of Aristotle to the study of real human nature encourages viewing in educational discourse abstract goal of "ideal man".

Why Twardowski, making an attempt to develop his own didactic theory, turned his attention to philosophy and pedagogy of Aristotle?

\section{4.}

Actualization in the educational discourse philosophical and pedagogical ideas of Aristotle by Twardowski took place largely through his teacher, the Austrian philosopher Brentano. Aristotle was an intellectual teacher for Brentano. He appealed the Aristotle's using of experience evidence in philosophy. Studying psychology of Aristotle by Brentano had significant impact on the content of his own Psychology from an Empirical Standpoint (1874). Similiarity of psychologies of these scientists is proved by the fact that both Brentano and Aristotle defined psychology as the science of the soul: "So it appears that just as the natural sciences study the properties and laws of physical bodies, which are the objects of our external perception, psychology is the science which studies the properties and laws of the soul, which we discover within ourselves directly by means of inner perception, and which we infer, by analogy, to exist in others" (Brentano, 2009: 4). Following Aristotle, Bren- 
tano believed that the human soul is a unity of three parts: the vegetative, sensory and intellectual (Brentano, 1867: 60-61). Refering in his work The Origin of the Knowledge of Right and Wrong (1902) to the words of Aristotle's Metaphysics "All men by nature seek knowledge", Brentano tried to emphasize the evident desire of everyone to virtues (Brentano, 1902: 19). However, philosopher emphasized the development of personal virtues, in particular „Innate dispositions are themselves diverse and much advance may be made by education and one s own ethical conduct. Enough, truth speaks, and whoever is of the truth hears her voice" (Brentano, 1902: 30).

Actualization in the educational discourse philosophical and pedagogical ideas of Aristotle by Twardowski was certainly caused by demand of revision the existing teaching projects. Philosopher's intention to review the purpose of education confirms his teaching maxim "learn not for school but for life" (non scholae sed vitae discimus) (Jadczak, 1992: 48). Before now Senecae distorted this phrase to "learn not for life but for school" (non vitae sed scholae dicsimus) (Senecae, CVI. 12). This was a kind of a blame to ancient Roman philosophers for exchenging by them the wisdom on every kind of rubbish - erudition. Modern German philosopher Peter Sloterdijk interpreted this satirical statement of ancient Roman philosopher as a ascertaining of school degradation which produces knowledge. Therefore, curriculum had to be broadcasted through other media means, such as through philosopher's correspondence with his younger friend (Слотердайк, 2014: 88). Sloterdijk also suggested that Senecae distorted this proverb by himself so, that authentic version non scholae sed vitae discimus looked for him quite reasonable. Twardowski also have returned to this version to proclaim teachers not to consider school the purpose of their activities. It was philosopher's radical response to teachers' conventional understanding life as just a survival. Following Aristotle, Twardowski explained that a person thirsts knowledge, above all, for its own sake, without thinking immediately about its benefits, "because satisfying curiosity, knowledge of something new itself is great pleasure for a person that brings significant satisfaction" (Twardowski, 2013: 511). Selfless desire for knowledge the philosopher considered ideal purpose of human life in which all desires for knowledge, strength and happiness converge (Twardowski, 2013: 523). He recognized intelligent people and people with characters the basis of state existence (Twardowski, 1997: 120).

Twardowski preferred heuristical form of learning, explaining that it is much more interesting to discover the truth by yourself, than to accept it passively from another through acromatical form of learning. As a supplement to heuristical form of learning he defined the science of things which aim is clear and detailed stud- 
ies of subjects' perception and creation on this basis their concepts (Twardowski, 1927: 49). But the scientist considered knowledge without the ability of their independent usage dead fund. He explained that "these children are spoken as those who really know a lot, but can not think" (Twardowski, 1901: 174). Since, the philosopher put on the school also the responsibility for students' intellectual abilities development.

The peculiarity of Twardowski's understanding of studying is the focus on upbringing learning. The philosopher saw school objectives in development child's virtues and qualities, thereby laying the foundations for character formation (Twardowski, 1901: 210). He strongly blamed those teachers who forgot about the moral ideals existence and tried to implement in school the interests of a particular social group, political party or organization (Twardowski, 2014b: 329). Thus, Twardowski associated the purpose of education with moral upbringing. Twardowski distinguished in moral education several stages. At the first stage a child accepts ethical norms and rules of behavior from adults. The second stage is associated with the development child's ability of reasoning his/her own moral choice based on formed feelings and desires. The third stage takes the form of self-education and lasts throughout life. Due to this approach, formed personality is not only able to act ethically, but also deliberately conclude norms of behavior (Twardowski, 1992: 417-421).

Twardowski defined psychology as auxiliary science of didactics. He explained that "a teacher, trying to make a positive impact on pupil's mind, giving him/her knowledge and developing his/her mental abilities must know the laws of intellectual life that affect pupil's learning and the development of his/her mental abilities. And psychology deals with these laws" (Twardowski, 1901: 12). However, the scientist designated psychology the basis of pedagogics as a science of education, justifying this by saying that "if moral education is the training of a will towards giving it the ability of making right decision, then psychology should show the way in which such training is carried out" (Twardowski, 1992: 417).

Consequently, we can conclude that Twardowski formed his views on education and upbringing based on the philosophical works of Aristotle and Brentano. He reflected discursive practices of his predecessors and tried to construct in educational space the image of a person not as educated as able to realize his/her abilities in life and society. Philosopher's optimism about the evidence of innate human desire for knowledge leads to overcoming dogmatism and formalism in education. If a person is able to understand how he/she should act in any social situation, he/she needs no instructions from above but promoting his/her self-development and self-actualization. According to Twardowski, psychology helps pedagogy in 
preparing pupil for independent living by describing the laws that regulate human behavior and activities. Actually, philosopher's narrative psychology lays in education foundations requirement to learn how it really is and a useless hope how it should be.

\section{5.}

The analysis of Yarema's and Twardowski's philosophical and pedagogical ideas leads to the conclusion that the Ukrainian scientist not only represented educational views of his philosophy teacher from university, but has also defined them. Yarema borrowed from Twardowski understanding of education as transmission of knowledge and the development of mental abilities and, most importantly, the formation of character and personality. Just as Twardowski, Yarema thought education is not "making" pupils according to the socio-economic needs of society. It is the basic human needs satisfaction and the culture broadcasting. Bogdan Nawroczyński, known representative of Twardowski's philosophical school, also insisted on the importance of this approach to education. Comparing the views of scientists on the purpose of education and upbringing can confirm this:

Twardowski:

"For a man knowledge and education can and must be something more than a means to easy the struggle for survival. The desire of education is the result of one of the noblest instincts of man is the result of thirst for knowledge" (Twardowski, 2014a: 323).

"School should be the civilizational center" (Twardowski, 1901: 224).

Yarema:

"The society of the twentieth century is hanging on school, searching here knowledge and, even more, rights for the better material life on earth" (Ярема, 2003a: 112).

"School directly plays a great civilizational role in this century. (...) Society must feel the civilization needs and understand better the school purpose" (Ярема, 2003a: 112-113).

Nawroczyński:

"neither so-called certificates of maturity, no even high school diplomas are the guarantee of education in a deep sense, whereas education is neither the sum of information, nor even the trained mind. Education is saturation the whole person with culture, including his/her intellect, feelings and abilities to action" (Nawroczyński, 1987: 38).

Yarema also adopted from Twardowski understanding that learning is not passive reflection of reality, but active making man's own knowledge of the world and his/her involvement in it. This Ukrainian scientist's view has been formed under 
Twardowski's influence, who considered cognition the creative act which does not need extraneous impulse or instruction for realization. The following quotes reflect Twardowski's influence on Yarema's ideas:

Twardowski:

"images appear in our minds as if by themselves, or through perception or memory or imagination. Usually images arise without making special efforts; in contrast, concept we create ourselves" (Twardowski, 1898: 140-141).

Yarema:

"The mental life begins with elementary phenomena - impressions which organize themselves in the psyche and turn into higher elements and systems - concepts and judgments. The psyche acts from the concrete to the abstract world, from real and evident manifestations to the invisible laws, from passive perception to the independent creation" (Ярема, 2003a: 114).

Yarema has also been influenced by Twardowski's views concerning correlation between teaching and upbringing. Polish philosopher supported upbringing through teaching. Upbringing meant for him the character development, the formation of ethical principles and will dispositions. The scientist defined honesty as one of human ethical duties. This is shown in his paper Honesty as an ethical duty (Prawdomowność jako obowiązek etyczny) (Twardowski, 1906: 84-85). This topic, as we can see, takes place in Brentano's philosophy. Actually, Yarema's report Upbringing to honеsty (Виховування до правдомовності) is also dedicated to this issue (Ярема, б/д: 30 арк.). He defined upbringing to honesty as general education, namely education of complete person from a moral point of view. In this report Ukrainian scientist expressed consonant with Aristotle, Brentano and Twardowski position concerning the difference between the life truth and the mental truth. Meanwhile Yarema focused on the same conditions for developing children's desire for the life truth, as his Polish philosophy teacher regarding education in general:

Twardowski:

"In order to obtain pupils sympathy the teacher should treat them always with the most kindness and condescension; pupils should make sure at every turn that the teacher wishes them only good: any sarcastic objurgation, any mock, derision or neglect of the pupils would be teacher's one of the hardest fault, as he/she should always have a heart for pupils and should always look into their hearts" (Twardowski, 1901: 206).

Yarema:

"Teachers must treat the pupils well, connecting their hearts. Teachers must treat pupils sincerely. They must evoke pupils' full trust and avoid any coercion violence" (Ярема, б/д: арк. 16). 
The comparisons, have been done in this paper, prove that Yarema supported Twardowski's discoursive practices in education, thereby promoting the education shift from standardization to individualization. However, it must be admitted that the problem of going education beyond the established parameters of functioning has still not been solved.

For instance, contemporary philosopher Natalia Savchuk explained the crisis of education as Yarema did almost hundred years ago. She relates it with the crisis of industrial civilization, which thinking, like ideologized, is alien to reflections as it is controlled by external in relation to man purposes. Natalia Savchuk assimilates the contemporary education with "spiritual production" where the ideas of formative, managed studying are realized, where a child is just a material and a teacher is "an operator" who controls the technology of educational process. "Such education, - the scientist says, - can not be the guarantor, even more the implementer of neither child rights no the contemporary quality of personality social becoming" (Савчук, 2006: 78). Instead, Savchuk defines the education objectives as taking into account human desires for freedom, independence, constructing his/her own senses of knowledge system and also creating the necessary conditions for personality development, self-actualization, self-realization (Савчук, 2006: 79).

Ken Robinson, famous British teacher also points out the troubles of modern schooling. In the mass "schools-factories" situation he calls for teachers to return to the basics, which aforetime Aristotle's attention was focused on. It is about human irrepressible thirst for knowledge. Because of this education, according to Ken Robinson requires only a personal approach. This means that teachers must take into account pupils' innate abilities and teach them differently. The curriculum should be flexible, so students were able to learn according to their interests and abilities. Pupils should be allowed to explore their interests and abilities, and only than they can fulfill themselves in life (Робінсон, 2016: 98). According to Robinson, the education should aim at giving the children possibilities to understand the environment as well as their own talents, so that they grew up happy and active people, humane citizens (Робінсон, 2016: 23).

In this context it is appropriate to mention the same Sloterdejk who condemns the practice of "equalization" in education, offering instead a demonstration of differences in it. The German philosopher considers comparison "moral infernal machine that devastates human live" (Слотердайк, 2014: 93). According to his opinion, one should run the life marathon "with that speed, which now suits my abilities and beliefs" (Ibid.). 
As we can see, the contemporary philosophers and teachers associate overcoming the world crisis in education with personality-oriented education. Therefore, Yarema's emphasized attention to human personal development in the educational area proves its current relevance. The Ukrainian scientist's philosophical and pedagogical ideas manifests in the present educational discourse understanding that only individualized teaching is a precondition for social progress. This means cultivating the cultural identity in education not in "the national issue" dimension, but on the world culture background. However, justifying by scientist the needs of psychological reflection in education, especially in its descriptive version as one of the sources of humanistic psychology, motivates modern educators to pay their attention on harmonizing their educational efforts with real human nature.

\section{6.}

After the demonstration of Yarema's philosophical and pedagogical ideas, examined in the context of Aristotle's, Brentano's and Twardowski's discoursive practices in education, we can give answers to the questions in this article. Thus, the analysis of Yakym Yarema's philosophical and pedagogical ideas shows that his views on the education objectives and psychological basis of pedagogic have been formed under the influence of Twardowski's practices, which goes back to Brentano's discoursive practices originated from Aristotle. Therefore, this paper can serve as a basis to identify educational issues in the phenomenon of Ukrainian brentanizm. Promising in this direction seems extrapolation psychological issues, raised in Yarema's manuscript The problems of unconscious mental processes (Проблеми несвідомих психічних проиесів, 1928) to the pedagogical area, since the main ideas of this manuscript are based on Brentano's achievements in empirical psychology (Ярема, 1928: арк. 1). At the same time, Yarema's philosophical and pedagogical views are similar to the current philosophical and pedagogical problems of identifying ways of overcoming the global crisis in education. But, whether Yarema's experience will be adopted and developed in Aristotle-Brentano-Twardowski dicoursive practices depends not as on how deep will this discourse be realized in education, as if we have enough desire and determination to be solidarity with these scientists in defining approaches to original personality formation in the changeable nowadays. As Aristotle claimed, human happiness does not depend on the vicissitudes of fate, but on the harmonization his/her activities with virtue (Aristotle, 1934: Nic. Eth. 1.11.). 


\section{References}

Aristotle (1934), Nicomachean Ethics, trans. H. Rackham, Cambridge; London http://data.perseus. org/catalog/urn:cts:greekLit:tlg0086.tlg010.perseus-eng1.

Aristotle (1944), Politics, trans. H. Rackham, Cambridge; London http://data.perseus.org/catalog/ urn:cts:greekLit:tlg0086.tlg035.perseus-eng1.

Aristotle (1989), Metaphysics, trans. H. Tredennick, Cambridge; London (first published 1933) http://data.perseus.org/catalog/urn:cts:greekLit:tlg0086.tlg025

Aristotle, On the Soul, trans. J. A. Smith. http://classics.mit.edu//Aristotle/soul.html.

Brentano F. (1867). Die Psychologie des Aristoteles, insbesondere seine Lehre vom Nous Poietikos. Mainz.

Brentano F. (1902). The Origin of the Knowledge of Right and Wrong. trans. C. Hague, London (first published 1889).

Brentano F. (2009). Psychology from an Empirical Standpoint. trans. A.C. Rancurello, D.B. Terrell, L.L. McAlister. London; New York (first published 1874).

Джоліф Д. (2003). Дискурс. [В:] Ч.Е. Вінквіст, В.Е. Тейлор (ред.) Енциклопедія постмодернізму. перекл. В. Шовкун, Київ, 126-128 (first published 2001).

Foucault M. (1972). The Archaeology of Knowledge. trans. A.M. Sheridan Smith. London (first published 1969).

Ivanyk S. (2014). Filozofowie ukraińscy w Szkole Lwowsko-Warszawskiej. Warszawa.

Jadczak R. (1992). Główne zasady pedagogiki Twardowskiego. [W:] K. Twardowski. Wybór pism psychologicznych i pedagogicznych, Warszawa, 42-55.

Nawroczyński B. (1987), Zasady nauczania [w:] Nawroczyński B. Dzieła wybrane. T. II. (wyb. A. Mońka-Stanikowa). Warszawa, 11-320. (first published 1930).

Робінсон К., Ароніка Л. (2016). Школа майбутнвого. Революиія у вашій школі, щзо назавжди змінить освіту. перекл. Г. Лелів, Львів (first published 2015).

Савчук Н. (2006), Ціннісно-смисловий простір освіти у вимірі внутрішнього стану індивіду [В:] Філособські абриси сучасної освіти (ред. Предборська І.), Суми, 60-82.

Senecae. L. Annaei, Epistularum moralium ad Lucilium liber septimvs decimvs et octavvs decimvs. http://www.thelatinlibrary.com/sen/seneca.ep17-18.shtml.

Слотердайк П. (2014). Ти мусиш змінити своє життя. перекл. М. Култаєва, Філософія освіти, № 1 (14): 76-95.

Twardowski K. (1898). Wyobrażenia i pojęcia. Lwów.

Twardowski K. (1901). Zasadnicze pojęcia dydaktyki i logiki do użytku w seminariach nauczycielskich i w nauce prywatnej. Lwów.

Twardowski K. (1906). Prawdomowność jako obowiązek etyczny. „Przegląd Filozoficzny”, R. IX, 84-85.

Twardowski K. (1927). Psychologia nauki pogladowej. [W:] K. Twardowski, Rozprawy i artykuly filozoficzne (zebr. i wyd. uczniowi). Lwów, 43-63 (first published 1899).

Twardowski K. (1992). O pojęciu wychowania. [W:] K. Twardowski, Wybór pism psychologicznych i pedagogicznych. Warszawa, 411-422 (first published 1911).

Twardowski K. (1997). Dzienniki. Cz. I. (red. Jadczak R.), Warszawa, Toruń.

Twardowski K. (2014b). Przemówienie na inauguracji IV roku Powszechnych Wykładów Uniwersyteckich. [W:] K. Twardowski. Myśl, mowa i czyn. Cz. II. (red. A. Brożek, J. Jadacki). Warszawa, 326-329 (first published 1902). 
Twardowski K. (2014a). Przemówienie na inauguracji III roku Powszechnych Wykładów Uniwersyteckich. [W:] K. Twardowski. Myśl, mowa i czyn. Cz. II. (red. A. Brożek, J. Jadacki), Warszawa, 321-326 (first published 1902).

Twardowski K. (2013). Dlaczego wiedza jest potęgą? [W:] K. Twardowski. Myśl, mowa i czyn. Cz. I. (red. Brożek A., Jadacki J.). Kraków, 510-523 (first published 1912).

Ярема Я. (1928). Педаsогічна психольогія. Прага.

Ярема Я. (2003а). На педагогічні теми. [В:] Яким Ярема (упор. і ред. Ярема С.). Львів, 109-117. (first published 1912).

Ярема Я. (2003b). Нова фаза у розвитку європейської школи [в:] Яким Ярема (упор. і ред. Ярема С.), Львів, 190-200. (first published 1934).

Ярема Я. (2003с). Психографія у школі. [В:] Яким Ярема (упор. і ред. Ярема С.), Львів, 118-152. (first published 1925).

\section{Archived materials}

Ярема Я (б/д), Виховування до правдомовності, Архів Якима Яреми. Науковий архів Наукової бібліотеки Національного університету «Києво-Могилянська академія», Фонд 12, Опис 1, Од. Збер. 49, Арк. 30. (рукопис).

Ярема Я (1937), Ступні морального розвитку, Архів Якима Яреми. Науковий архів Наукової бібліотеки Національного університету «Києво-Могилянська академія», Фонд 12, Опис 1, Од. Збер. 48, Арк. 19. (рукопис).

Ярема Я (1928), Проблеми несвідомих психічних процесів, Архів Якима Яреми. Науковий архів Наукової бібліотеки Національного університету «Києво-Могилянська академія», Фонд 12, Опис 1, Од. 36ер. 45, Арк. 80. (рукопис). 